\title{
PEMANFAATAN ARANG BATOK KELAPA DAN TANAH HUMUS BATURRADEN UNTUK MENURUNKAN KADAR LOGAM KROM (Cr)
}

\author{
Anung Riapanitra dan Roy Andreas \\ Program Studi Kimia, Jurusan MIPA, Fakultas Sains dan Teknik UNSOED
}

\begin{abstract}
Waste containing hazardous and toxic chemical compounds into the environment leads to water pollution, soil and air. These chemical compounds will endanger human life and environment. One type of compound that may pollute the environment is chromium. The metal is commonly found in industrial waste such as from exhaust and industrial wastewater from etal plating company.

The purpose of this research is to utilize coconut shell charcoal and soil humus as a low-cost and ready-made alternative material to reduce the concentration chromium $(\mathrm{Cr})$ on wastewater. Humus was taken from Baturraden region and was isolated using $\mathrm{NaOH}$ extraction and was furthermore purified using mixtures of $\mathrm{HF}_{(\mathrm{aq})}$ : $\mathrm{HCl}_{(\mathrm{aq})}$. Coconut shell charcoal was produced and was mixed with the humus. Adsorption process was carried out by batch method on variations of charcoal: humus composition, $\mathrm{pH}$, and contact time. Humus soil was identified using infrared spectrophotometry (IR). Determination of chromium concentration was performed using atomic absorption spectroscopy (AAS).

The purified humus yielded was $25.92 \%$ (w/w), with $34.18 \%$ moisture, and ash content of $18.09 \%$. The results showed that the variation of composition ratio of $2: 1$ charcoal and humus produced the greatest percent reduction of $18.20 \%$, and the optimum $\mathrm{pH}$ for the adsorption is 9 . For the variation of contacts time, the optimum reaction time is at 180 minutes with decreasing concentration of $\mathrm{Pb}$ up to $56.07 \%$.
\end{abstract}

\section{Keyword: Charcoal, humic substances, adsorption, chromium}

\section{PENDAHULUAN}

Zat-zat pencemar dalam lingkungan air umumnya adalah unsur dan senyawaan anorganik. Unsur-unsur anorganik dapat berupa logam-logam seperti $\mathrm{Cd}, \mathrm{Cr}, \mathrm{Co}, \mathrm{Cu}, \mathrm{Zn}, \mathrm{Pd}, \mathrm{Hg}, \mathrm{Ni}$, dan Ag. Logam Krom (Cr) merupakan logam yang digunakan dalam industri knalpot dan perbengkelan lainnya sebagai pelapis logam. Logam krom merupakan salah satu logam limbah bahan beracun dan berbahaya (B3). Berbagai metode dapat dilakukan untuk proses penghilangan logam dalam perairan misalnya dengan sistem pertukaran ion, reduksi kimia, osmosis balik, filtrasi membran, adsorpsi dan sebagainya. Sebagian besar metode ini hanya dapat diterapkan untuk industri skala besar. Metode-metode ini memiliki kebutuhan infrastruktur yang mahal, oleh karena itu diperlukan suatu sistem penghilangan logam yang berskala kecil, efisien dan sebisa mungkin dapat diciptakan sendiri.

Salah satu usaha yang efisien dan murah untuk penurunan kadar logam di perairan adalah dengan sistem adsorpsi. Beberapa penelitian terdahulu, misalnya oleh Perdana (2007) mengadsorpsi limbah buatan krom menggunakan abu sekam padi, sedangkan Taliwongso (2005) mempergunakan lignin. Bahan adsorben yang sering digunakan antara lain karbon aktif, tanah diatomae, zeolit dan lain-lain. Bahan alternatif lain yang dapat digunakan sebagai adsorben adalah tanah humus. Dalam perkembangannya, penggunaan material adsorben dapat disederhanakan maupun dikombinasikan untuk menambah performa adsorpsi. 
Penggunaan arang sebagai adsorben dan tanah humus yang memiliki sifat penukar ion diharapkan dapat meningkatkan performa dalam menurunkan kadar logam krom. Arang digunakan tanpa pengaktifan merupakan solusi praktis agar masyarakat mudah memanfaatkannya, karena biaya pembuatannya akan lebih rendah dibandingkan arang aktif. Berdasarkan pernyataan di atas maka telah dilakukan penelitian tentang penggunaan arang batok kelapa dan tanah humus dari Obyek Wisata Baturraden untuk menurunkan kadar logam krom

\section{METODE PENELITIAN}

\section{Bahan dan Alat}

Bahan-bahan yang digunakan dalam penelitian ini adalah tanah humus, arang batok kelapa, kalium bikromat, $\mathrm{NaOH}, \mathrm{HCl}, \mathrm{HF}, \mathrm{H}_{2} \mathrm{SO}_{4}$, akuades, kertas saring Whatman, kertas saring, kain net, kalium hidrogen ftalat, $\mathrm{CH}_{3} \mathrm{COONa} .3 \mathrm{H}_{2} \mathrm{O}, \quad \mathrm{Na}_{2} \mathrm{HPO}_{4} .2 \mathrm{H}_{2} \mathrm{O}$, $\mathrm{Na}_{2} \mathrm{~B}_{4} \mathrm{O}_{7} \cdot 10 \mathrm{H}_{2} \mathrm{O}$, dan $\mathrm{NaHCO}_{3}$.

Alat-alat yang digunakan dalam penelitian ini adalah Spektrofotometer Infra Merah IR Shimadzu FTIR-8201PC, spektrometer Serapan Atom PerkinElmer 3100PC, desikator, mortar, ayakan 85 mesh, ayakan 120 mesh, sentrifus, neraca analitik, muffle furnace, $\mathrm{pH}$ meter, shaker, dan alat- alat gelas.

\section{Prosedur Penelitian \\ Isolasi dan Pemurnian Tanah Humus}

Tanah humus diisolasi dari Wanawisata Baturraden Purwokerto. Sampel tanah dibersihkan dari kerikil dan pengotor. Sebanyak 1000 gram sampel tanah yang telah dibersihkan, diekstraksi dengan larutan $\mathrm{NaOH} 0,5 \mathrm{M}$ dengan media plastik ukuran 1,5 liter, ditutup rapat dan dikocok dengan bantuan shaker selama 24 jam. Residu ekstraksi dipisahkan dari larutan dengan didekantasi. Selanjutnya, dilakukan pengasaman dengan menambahkan $\mathrm{HCl}$
$6 \mathrm{M}$ hingga $\mathrm{pH}<2$. Residu disaring dengan saringan buchner, dibilas dengan larutan $\mathrm{HCl}$ 0,01 $\mathrm{M}$ dan dibebas ion kan dengan akuades kemudian dikeringkan diudara.

Ekstraksi tanah humus dilanjutkan dengan tahap pemurnian. Tanah humus kotor dimurnikan dengan larutan campuran $\mathrm{HF}-\mathrm{HCl}$ sebanyak 2 tahap. Tahap pertama, humus kotor dicampur dengan $(1: 1 \mathrm{v} / \mathrm{v}) 0,2 \mathrm{M} \mathrm{HCl}$ dan 0,2 M HF selama 64 jam lalu disaring. Tahap kedua, residu yang diperoleh dimasukkan dalam campuran 1:1 $\mathrm{HF}(5,5 \mathrm{M})$ dan $\mathrm{HCl}(1,1 \mathrm{M})$ selama satu jam, masing-masing didekantasi dan dibilas dengan $0,1 \mathrm{M} \mathrm{HCl}$ dan terakhir dibilas dengan akudes hingga netral. Residu yang diperoleh merupakan tanah humus yang bebas pengotor. Selanjutnya tanah humus dikeringudarakan dan diayak dengan ayakan 120 mesh lalu disimpan dalam desikator

\section{Pembuatan Arang Batok Kelapa}

Batok kelapa dibersihkan, dikeringkan di bawah sinar matahari ditimbang bobotnya, kemudian diarangkan dengan tanur pada suhu $350^{\circ} \mathrm{C}$ selama 3,5 jam setelah itu tanur dibiarkan dingin dan arang didinginkan, kemudian diayak dengan ayakan 85 mesh, dihitung rendemennya, kadar air dan kadar abunya, disimpan dalam desikator.

Kadar air dihitung dengan memasukkan $2 \mathrm{~g}$ arang dalam cawan porselen dan dioven pada suhu $105^{\circ} \mathrm{C}$ selama 3 jam didinginkan lalu ditimbang dan dihitung menggunakan rumus:

kadar air $(\%)=\left(\frac{(a-b)}{a} \times 100 \%\right)$

$\mathrm{a}=$ bobot arang mula-mula $(\mathrm{g})$

$\mathrm{b}=$ bobot setelah dikeringkan $(\mathrm{g})$

Kadar abu dihitung dengan menimbang 2 $\mathrm{g}$ arang dalam cawan porselen yang diketahui bobotnya dipijarkan pada suhu 
$600^{\circ} \mathrm{C}$ selama 3 jam lalu dihitung menggunaan rumus:

kadar abu $(\%)=\left(\frac{(a-b)}{a} \times 100 \%\right)$

$\mathrm{a}=$ berat abu konstan $(\mathrm{g})$

$\mathrm{b}=$ berat arang konstan $(\mathrm{g})$

\section{Pembuatan Adsorben Campuran Arang dan Tanah Humus}

Arang dan tanah humus disusun dalam susunan sandwich dengan perbandingan arang:humus yaitu 1:1, 1:2, dan 2:1. Humus diletakkan dibagian tengah layer dengan cetakan yang telah dilapis pembungkus kain net dan kertas saring. Selanjutnya lapisan dengan volume $30 \mathrm{~cm}^{3}$ dibungkus dengan kain net dan kertas saring.

Adsorpsi krom (Cr) pada penelitian ini dilakukan dengan menggunakan metode batch. Briket campuran tanah humus dan arang yang telah dibungkus digantung pada bagian klem dan ditempatkan pada larutan tanpa mengenai magnet stirrer supaya adsorben tidak rusak, dan stirrer dijalankan pada kecepatan $120 \mathrm{rpm}$. Kadar krom dalam bikromat ditentukan pada tiga perbandingan arang dan humus dengan mengukur absorbansi sampel menggunakan Spektrofotometer Serapan Atom (SSA) Perkin-Elmer 3100PC pada proses adsorpsi selama satu jam pada suhu kamar $\left(29^{\circ} \mathrm{C}\right)$. Pengukuran adsorbansi sampel dilakukan secara triplo.

\section{Penentuan Pengaruh pH}

Adsorben arang dan humus perbandingan $1: 1, \quad 1: 2$, dan $2: 1$ di interaksikan dengan larutan standar krom (Cr) $30 \mathrm{ppm}$ pada variasi $\mathrm{pH} \mathrm{3,5,} \mathrm{7,} \mathrm{9,}$ dan 11. $\mathrm{pH}$ larutan ditentukan dengan menggunakan $\mathrm{pH}$ meter yang dikalibrasikan dengan buffer $\mathrm{pH}$ 4,0 dan 9,2. Absorbansinya diukur dengan SSA.

\section{Penurunan Kadar Krom Limbah Cair}

Proses adsorpsi dilakukan dengan metode batch pada suhu kamar. Material adsorben ditambahkan dengan $250 \mathrm{~mL}$ larutan standar krom cair dengan konsentrasi $30 \mathrm{ppm}$. Analisis penurunan kadar krom dilakukan pada $\mathrm{pH}$ optimal dan variasi waktu yaitu 10 menit; 30 menit; 1 jam; 2 jam; 3 jam; 6 jam; 24 jam; dan 48 jam. Campuran tersebut digoyang dengan shaker pada kecepatan 120 rpm. Kadar logam setelah diinteraksikan diukur dengan SSA.

$\%$ penurunan kadar $\mathrm{Cr}$ dapat ditentukan dengan rumus:

$$
\text { Persen removal }(\%)=\left(\frac{\left(c_{0}-c_{t}\right)}{c_{0}} \times 100 \%\right)
$$

Dimana $\mathrm{C}_{0}$ adalah konsentrasi awal dan $\mathrm{Ct}$ adalah konsentrasi setelah adsorpsi.

\section{HASIL DAN PEMBAHASAN Isolasi dan Pemurnian Tanah Humus}

Sampel tanah humus yang digunakan dalam penelitian ini berasal dari hutan di sekitar bukit Cendana, kawasan wanawisata Baturraden. Humus yang diambil berasal dari daerah non kawasan pertanian dan diperkirakan masih murni dari adanya pengotorpengotor artifisial. Tanah humus yang digunakan mempunyai karakteristik yaitu berwarna cokelat kehitam-hitaman.

Sampel tanah humus kemudian dibersihkan dan diekstraksi dengan $\mathrm{NaOH} \quad 0,5 \quad \mathrm{M}$, bertujuan untuk mengisolasi tanah humus dan menghasilkan tanah humus yang mengandung mineral. Menurut Levesque and Schnitzer (1966), larutan alkalis mulai kadar 0,1 M dapat mengekstraksi tanah humus dan untuk kadar 0,5 M dapat memberikan hasil dengan kadar abu rendah. Menurut Brucket (1979) dalam Pansu dan Goutheyrou (2003). Metode ekstraksi alkalis merupakan metode yang paling kuat dalam mengekstraksi humus dari sampel tanah, namun penggunaan metode ini dikritik karena tiga alasan, antara lain terbentuknya formasi baru dari struktur bahan non humat yang tidak dapat larut 
seperti polisakarida, lignin, dan protein yang berasal dari sisa-sisa tanaman; terdegradasinya struktur bahan humat karena mengalami reaksi hidrolisis, oksidasi, dan pembentukan polimer; serta larutan alkalis dapat memecahkan dinding sel bakteri pada tanah, dinding sel tersebut merupakan residu yang sulit diekstrak.

Hal diatas dapat diatasi dengan cara pengeringan yang sempurna dan membersihkan tanah tersebut dengan cara diayak. Proses ini bertujuan memisahkan sisa-sisa tanaman, pasir, dan batuan dalam proses ekstraksi untuk mencegah reaksi degradasi tanah humus. Selama proses isolasi, hampir seluruh bagian menjadi residu yang bisa dinetralkan dan dikeringkan dan tidak terdapat pengotor yang dapat teramati secara fisik.

Sampel tanah yang telah diekstraksi dengan larutan natrium hidroksida $(\mathrm{NaOH}) \quad 0,5 \quad M \quad$ dishaker selama 24 jam, kemudian diambil endapannya. Menurut Schnitzer (1972), tujuan utama dari pemurnian tanah humus ialah untuk meminimalisir kadar abu dalam humus, sehingga didapat tanah humus murni dengan kadar abu rendah.
Sampel tanah humus selanjutnya dimurnikan dengan modifikasi proses pemurnian humin, yaitu dengan ekstraksi campuran humus dan larutan campuran $\mathrm{HF}-\mathrm{HCl}$ hingga diperoleh tanah humus murni (Aiken et al., 1985).

Menurut Pansu dan Goutheyrou (2003), penggunaan $\mathrm{HF}-\mathrm{HCl}$ dilaporkan merupakan pereaksi yang paling efektif dalam memurnikan tanah humus. Hasil spektroskopi infra merah pada tanah humus yang telah dimurnikan dengan $\mathrm{HF}-\mathrm{HCl}$ menunjukkan bahwa proses pemurnian dapat sempurna menghilangkan intensitas dari bilangan gelombang dari mineral silikat pada 470 , 520 dan $1030 \mathrm{~cm}^{-1}$. Penurunan mineral silikat pada tanah humus yang dimurnikan akan menurukan kadar abu. Hal ini didukung data penelitian yaitu turunnya kadar abu sebesar 3\%.

\section{Karakteristik Humus Hasil Isolasi}

Humus hasil isolasi dari hutan di sekitar bukit Cendana, kawasan wanawisata Baturraden dikarakterisasi dengan mengukur rendemen, kadar air, dan kadar abunya. Hasil pengukuran dapat dilihat pada Tabel 1 berikut:

Tabel 1. Rendemen, Kadar Air, dan Kadar Abu Humus Hasil Isolasi

\begin{tabular}{llll}
\hline Humus & Rendemen $(\%)$ & Kadar Abu (\%) & Kadar Air (\%) \\
\hline Humus Sebelum pemurnian & 60,23 & 68,01 & 20,59 \\
Humus Murni & 25,92 & 34,18 & 18,09 \\
\hline
\end{tabular}

Berdasarkan data dalam Tabel 1 dapat diketahui bahwa rendemen humus murni yang diperoleh menggunakan metode ekstraksi alkali yaitu sebesar 25,92\% (b/b) dari 15 gram sampel yang tanah yang diekstraksi karena humus murni telah bersih dari pengotor seperti mineral - mineral silika yang tertinggal dan tidak larut terhadap $\mathrm{NaOH}$, karena mengalami proses pemurnian yang berulang menggunakan campuran HF-HCl. Kadar abu humus kotor dan humus murni memiliki perbedaan yang cukup besar, yaitu $68,01 \%$ untuk humus kotor dan
$34,18 \%$ untuk humus murni. Perbedaan ini menunjukkan bahwa campuran HF$\mathrm{HCl}$ dapat mengurangi jumlah pengotor pengotor anorganik dalam humus kotor. Efektifitas dari proses pemurnian akan makin tinggi apabila makin banyak mineral yang hilang dari humus. Abu yang dihasilkan pada pembakaran temperatur tinggi merupakan mineral mineral logam dalam suatu bahan, maka penetapan kadar abu dapat digunakan sebagai ukuran keberhasilan suatu proses pemurnian. Kadar air humus sebelum pemurnian dan humus murni mempunyai 
perbedaan yang tidak terlalu besar, yaitu $20,59 \%$ untuk humus kotor dan 18,09\% untuk humus murni. Menurut Cowd (1991), Tinggi rendahnya kadar air dipengaruhi oleh metode dan lamanya pengeringan, kelembaban udara relatif, serta tempat penyimpanan.

\section{Analisis Kualitatif Gugus Fungsional Humus}

Humus hasil isolasi sebelum dan sesudah dimurnikan dianalisis dengan menggunakan spektrofotometer inframerah Shimadzu FTIR-8210PC dengan sel $\mathrm{KBr}$ untuk mengetahui adanya gugus fungsional humus yang diharapkan mengandung gugus $-\mathrm{COOH}$ dan $\mathrm{OH}$ fenolat. Spektra hasil analisis ini digunakan untuk mengidentifikasi gugusgugus fungsi yang terdapat pada humus hasil isolasi, terutama pada serapan $\mathrm{COOH}, \quad-\mathrm{OH}$ dan $-\mathrm{C}=\mathrm{O}$, spektra inframerah juga dapat digunakan untuk mengetahui efektivitas pemurnian humus kotor dengan menggunakan campuran larutan HF-HCl. Hasil analisis FTIR humus sebelum dimurnikan dapat dilihat pada Gambar 1. dan sesudah dimurnikan humus dapat dilihat pada Gambar 2.
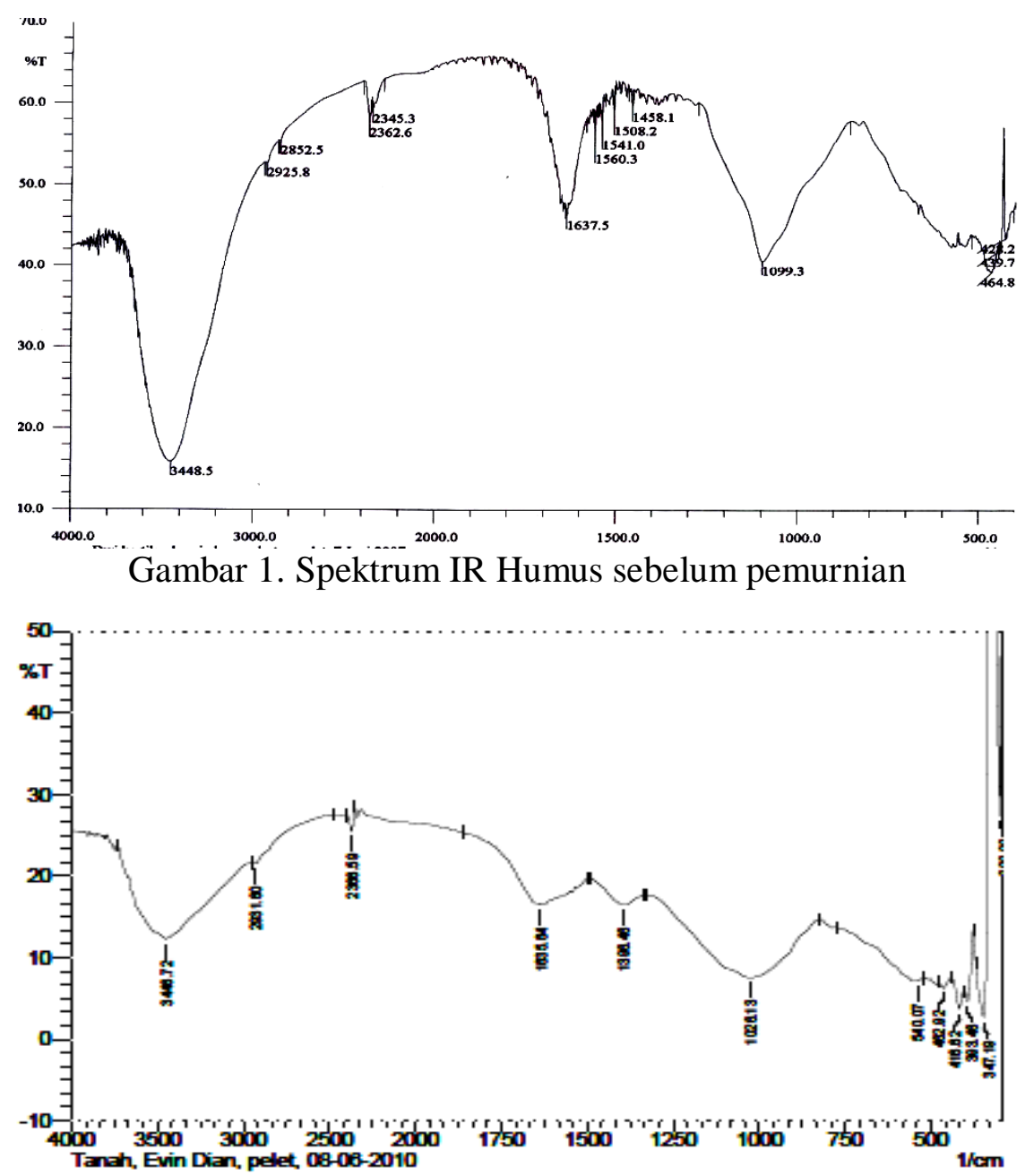

Gambar 2. Spektrum IR Humus setelah pemurnian

Berdasarkan Gambar 1 dan Gambar 2, pemurnian humin kotor menggunakan campuran $\mathrm{HF}-\mathrm{HCl}$ digunakan untuk menghilangkan ion-ion logam dan pasir 
silikat yang menjadi pengotor pada humin yang berada pada puncak serapan bilangan gelombang 1099,3 $\mathrm{cm}^{-1}$ yang mengindikasikan adanya vibrasi ulur dari Si-O dari silikat $\left(\mathrm{SiO}_{2}\right)$ pada humin kotor. Menurut Silverstein, et al. (1981), vibrasi ulur $\mathrm{Si}-\mathrm{O}$ dari silikat $\left(\mathrm{SiO}_{2}\right)$ terjadi pada bilangan gelombang $1110-1000 \mathrm{~cm}^{-1}$. Sedangkan pada pemurnian humus masih terdapat $\mathrm{SiO}_{2}$ yaitu pada puncak bilangan gelombang 1026,13 $\mathrm{cm}^{-1}$ yang mengindikasikan masih adanya vibrasi ulur $\mathrm{SiO}_{2}$ dari silikat $\left(\mathrm{SiO}_{2}\right)$ pada humus yang dimurnikan murni.

Menurut Silverstein, et al. (1981), munculnya puncak pada bilangan gelombang $850-550 \mathrm{~cm}^{-1}$ diakibatkan ikatan antara atom $\mathrm{C}$ dengan satu atau beberapa ion klorida. Bilangan gelombang 540,07 $\mathrm{cm}^{-1}$ diakibatkan oleh adanya ion $\mathrm{Cl}^{-}$yang berikatan dengan atom C. Adanya ikatan tersebut disebabkan masih tertinggalnya ion-ion $\mathrm{Cl}$ pada saat pencucian humus. Puncak serapan 462,92 $\mathrm{cm}^{-1}$ dan 416,62 $\mathrm{cm}^{-1}$ disebabkan oleh adanya mineral lempung (Phyllosilicates). Menurut Pansu dan Goutheyrou (2003), puncak serapan dari Phyllosilicates yaitu sekitar $470 \mathrm{~cm}^{-1}$. Hal ini menandakan humus murni mengandung mineral lempung, namun intensitasnya lebih sedikit dibanding humus kotor dimana humus kotor mempunyai puncak serapan yang lebih tinggi dibandingkan dengan humus murni.

Pemurnian humus kotor menjadi humus murni ditunjukkan dengan adanya puncak pada bilangan gelombang $1635,64 \mathrm{~cm}^{-1}$ pada humus murni yang mengindikasikan adanya gugus karboksil (-COO-) yang membuktikan bahwasanya proses pemurnian tidak merusak gugus fungsional humus. Menurut Tan (1995), pada panjang gelombang ini terjadi akibat dari stretching gugus $-\mathrm{COO}^{-}$ asimetri pada humus. Panjang gelombang $3448,72 \mathrm{~cm}^{-1}$ pada humus murni mengindikasikan adanya gugus $-\mathrm{OH}$ dan gugus $-\mathrm{OH}$ fenolat. Menurut Silverstein, et al. (1981), serapan gugus $-\mathrm{OH}$ dan gugus $-\mathrm{OH}$ fenolat terjadi pada bilangan gelombang 3300-3600 $\mathrm{cm}^{-1}$ dengan intensitas sedang. Bilangan gelombang $1635,6 \mathrm{~cm}^{-1}$ menunjukkan vibrasi ulur $\mathrm{C}=\mathrm{C}$ aromatik atau $\mathrm{C}=\mathrm{O}$ (keton terkonjugasi) mengikat hidrogen, sedangkan bilangan gelombang $2931 \mathrm{~cm}^{-}$ 1 merupakan vibrasi ulur $\mathrm{C}-\mathrm{H}$ alifatik (Aiken, et al., 1985).

Dari data spektroskopi IR menunjukkan bahwa humus belum termurnikan secara sempurna dan proses pemurnian yang dilakukan tidak mendegradasi struktur bahan humat.

\section{Pembuatan Arang Batok Kelapa}

Rendemen, kadar air dan kadar abu dapat dilihat pada Tabel 2 .

Tabel 2. Rendemen, Kadar Air, dan Kadar Abu Arang Batok Kelapa

\begin{tabular}{lll}
\hline $\begin{array}{l}\text { Rendemen } \\
(\%)\end{array}$ & $\begin{array}{c}\text { Kadar } \\
\text { Abu }(\%)\end{array}$ & $\begin{array}{c}\text { Kadar } \\
\text { Air }(\%)\end{array}$ \\
\hline 90,59 & 13,48 & 9,40 \\
\hline
\end{tabular}

Menurut Andreas, dkk., (2006) efektifitas proses pemurnian humus akan makin tinggi apabila makin banyak mineral yang hilang dari humus. Abu yang dihasilkan merupakan residu proses pembakaran humus pada temperatur tinggi yaitu mineral, maka kadar abu dapat digunakan sebagai ukuran kebersihan suatu proses pemurnian. Makin efektif proses pemurnian maka kadar abu semakin sedikit.

\section{Pembuatan Campuran Tanah Humus dan Arang}

Arang batok kelapa dan tanah humus yang diperoleh disusun dengan perbandingan arang: humus sebesar 1:1, 1:2 dan 2:1. Campuran keduanya kemudian diletakkan dalam cetakan dan dilapisi pembungkus kain net dan atau kertas saring. Berdasarkan hasil percobaan yang diperoleh bahwa kertas saring mampu menahan kebocoran dari 
tanah humus maupun arang batok kelapa hingga selama 48 jam dimana terlihat dari stabilnya waktu kesetimbangan adsorpsi sebagaimana dibahas pada penentuan waktu optimum adsorpsi. Kain net yang berlapis-lapis tidak mampu menahan bocornya tanah humus maupun arang batok kelapa. Hal ini disebabkan oleh sifat dari arang dan humus membentuk koloid pada pelarut air. Tanah humus yang telah disaring hingga 120 mesh membutuhkan penahan dengan pori yang mampu menahan hingga 120 mesh dan kertas saring ternyata mampu menahan bocornya arang dan humus. Humus dalam pelarut air akan cenderung membentuk koloid yang akan dengan mudah ditengarai dari perubahan warna larutan menjadi coklat keruh, sedangkan arang tidak dapat larut dalam pelarut air dan membentuk suspensi.

\section{Adsorpsi Krom (Cr) oleh Campuran Humus dan Arang Batok Kelapa}

Perbandingan penurunan

konsentrasi krom pada variasi perbandingan konten adsorben dapat dilihat pada Tabel 3. Perbandingan arang batok kelapa: tanah humus 2:1 adalah yang tertinggi dan digunakan untuk menentukan $\mathrm{pH}$ optimal.

Tabel 3. Penurunan Kadar Krom (Cr) pada Variasi Perbandingan Konten Adsorben

\begin{tabular}{cc}
\hline Perbandingan & Penurunan \\
(Arang: Humus) & $(\%)$ \\
\hline $1: 1$ & 13,81 \\
$1: 2$ & 11,96 \\
$2: 1$ & 18,20 \\
\hline
\end{tabular}

\section{Penentuan pH Optimum Adsorpsi}

$\mathrm{pH}$ optimum adsorpsi diperoleh dengan melakukan proses adsorpsi pada berbagai $\mathrm{pH}$ yang dilakukan selama 1 jam pada suhu kamar $\left(29^{\circ} \mathrm{C}\right)$. Variasi $\mathrm{pH}$ adsorpsi dilakukan pada $\mathrm{pH}$ 3,5,7,9 dan 11. Adsorben menggunakan perbandingan konten yaitu arang batok kelapa: tanah humus 2:1. Diketahui bahwa $\mathrm{pH}$ optimum didapat pada $\mathrm{pH} 9$ ialah sebesar 48,52\%. Penurunan kadar Krom $(\mathrm{Cr})$ pada variasi $\mathrm{pH}$ dapat dilihat pada Tabel 4.

Tabel 4. Penurunan Kadar Krom (Cr) pada Variasi $\mathrm{pH}$

\begin{tabular}{cc}
\hline $\mathrm{pH}$ & Penurunan $(\%)$ \\
\hline 3 & 36,96 \\
5 & 13,08 \\
7 & 19,46 \\
9 & 48,52 \\
11 & 36,34 \\
\hline
\end{tabular}

Menurut Sujandi (2002), pH basa dapat menyebabkan gugus fungsional dipermukaan mengalami deprotonasi, sehingga pada saat yang sama terjadi kompetisi antara gugus fungsional dan ion alkali dalam berikatan dengan ion logam. Pada $\mathrm{pH}$ basa banyak terdapat ion-ion alkali antara lain $\mathrm{OH}^{-}, \mathrm{HCO}_{3}{ }^{-}$, dan $\mathrm{CO}_{2}^{-}$. Hal ini menyebabkan jumlah krom yang teradsorpsi meningkat. Menurut Arivoli et al. (2008), Saat pH larutan tinggi, ion-ion krom akan lebih mudah tertarik ke permukaan adsorben yang bermuatan negatif, sehingga mengakomodasi terjadinya adsorpsi. Sedangkan pada $\mathrm{pH}$ yang rendah terjadi persaingan antara ion logam dan proton sehingga adsorpsi terhambat. Lebih lanjut, terbentuknya beberapa spesi hidrokso dalam larutan akan meningkatkan adsorpsi untuk adsorben berbahan baku arang (Arivoli, 2007).

\section{Penentuan Waktu Optimum Adsorpsi}

Waktu optimum adalah waktu yang dibutuhkan agar adsorpsi terjadi secara maksimum. Analisis penurunan kadar krom dilakukan pada $\mathrm{pH}$ optimal dan variasi waktu yaitu 10 menit; 30 menit; 1 jam; 2jam; 3 jam; 6 jam ;12 jam; 24 jam dan 48 jam. Kurva penurunan kadar Krom $(\mathrm{Cr})$ menggunakan campuran humus dan arang batok kelapa dengan 


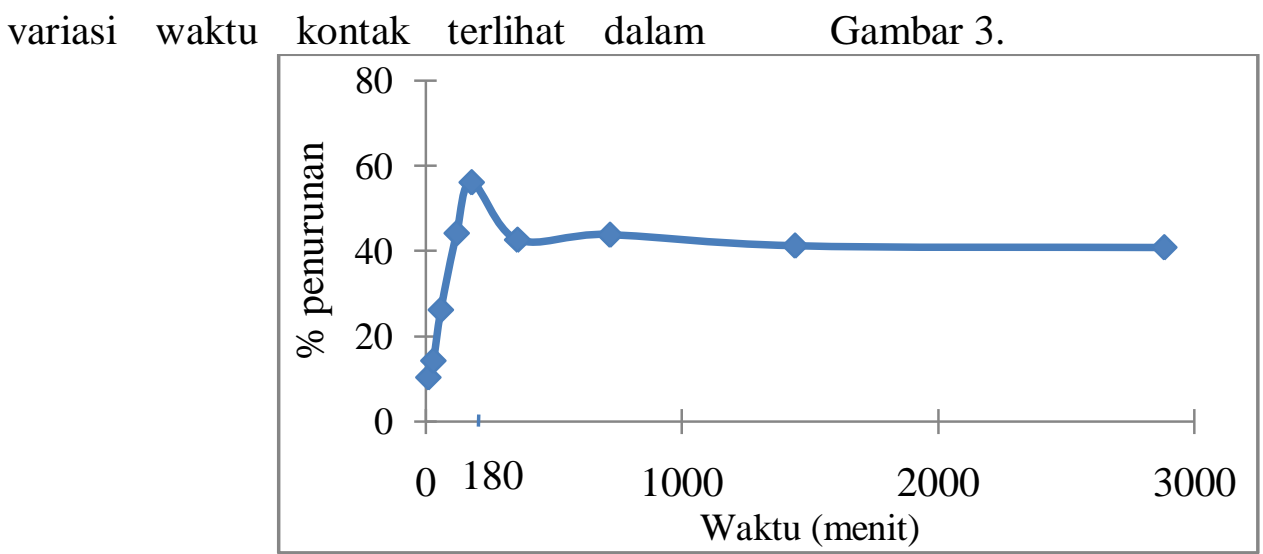

Gambar 3. Kurva Penurunan Kadar Krom (Cr) pada Variasi Waktu Kontak

Hasil pengukuran pada SSA diperoleh pada waktu kontak selama tiga jam menghasilkan persen penurunan paling besar dibanding dengan waktu kontak yang lain yaitu sebesat $56,07 \%$. Setelah tiga jam terjadi kesetimbangan adsorpsi. Waktu kesetimbangan adsorpsi menurut Lubis dan Nasution (2002), merupakan suatu keadaan dimana permukaan adsorben yang telah jenuh oleh molekul teradsorpsi tidak mampu lagi meningkatkan daya adsorpsinya meskipun konsentrasi adsorbatnya diperbesar. Adamsons (1976) menambahkan, adsorpsi yang terjadi oleh materi adsorben setelah mencapai kesetimbangan, serapannya cenderung tetap atau bahkan menurun.

\section{KESIMPULAN}

Campuran arang batok kelapa dan tanah humus dapat digunakan sebagai adsorben untuk menurunkan kadar logam krom walaupun tidak sempurna. Persen penurunan kadar logam krom terbesar menggunakan kombinasi arang batok kelapa dan tanah humus 2:1 dan pada $\mathrm{pH}$ optimum 9 yaitu sebesar 48,516\%. Persen penurunan kadar logan krom pada waktu kontak optimum tiga jam yaitu sebesar 56,07\%.

\section{UCAPAN TERIMA KASIH}

Kami mengucapkan terimakasih kepada Unsoed yang telah mendanai penelitian ini melalui scheme DIPA I 2010, serta kepada Evin Dian Irnawati selaku mahasiswa skripsi pelaksana penelitian ini.

\section{DAFTAR PUSTAKA}

Adamsons, W.A., 1976, Physical Chemistry of Surface, Interscience, New York

Aiken, GR, D.M. McKnight, R.L. Wershaw, dan P. MacCharthy, 1985, "Humic Substances in Soil Sediment and Water : Geochemistry, Isolation, and Characterization”, John Wiley \& Son, New York.

Andreas, R., Narsito dan S. Noegrohati, 2006, Karakteristik Adsorpsi Tembaga (II) Pada Humin Dalam Medium Air Tawar, Jurnal Ilmiah Kimia, Vol 1, 1-9.

Arivoli S, 2007, Kinetic and thermodynamic studies on the adsorption of some metal ionsand dyes onto low cost activated carbons, Ph D., Thesis, Gandhigram Rural University, Gandhigram. 
Arivoli, S., M Hema, M. Karuppaiah And S. Saravanan, 2008, Adsorption of Chromium Ion by Acid Activated Low Cost CarbonKinetic, Mechanistic, Thermodynamic and Equilibrium Studies. E-Journals of Chemistry, Vol. 5, No.4, pp. 820-831

Cowd, M.A., 1991. Kimia Polimer. ITB, Bandung

Lévesque and Schnitzer, 1966, Effects of $\mathrm{NaOH}$ concentration on the extraction of organic matter and of major inorganic constituents from a soil, J. Soil Sci., 46, 7-12.

Pansu M, and J. Gautheyrou, 2003, Handbook of soil Analysis : Mineralogical, Organic and Inorganic Methods, SpringerVerlag,New York.

Perdana, N.R.W, 2007, Adsorpsi Cr (VI) dengan menggunakan Abu Sekam Padi sebagai Adsorbent, Skripsi, Institut Teknologi Surabaya, Surabaya
Schnitzer, M., and S.U. Khan, 1972, Humic Substances in the Environment, Dekker, New York.

Silverstein, R.M., G. C. Bassler, and T. C. Morril, 1981, Spectrometric Identification of Organic Compounds $4^{\text {th }}$ Edition, John Willey and Sons, Inc.

Sujandi, 2002, Immobilisasi Asam Humat pada Permukaan Silika Gel dan Aplikasinya untuk Adsorpsi Tembaga (II) dan Kalsium (II), Skripsi, Jurusan Kimia, FMIPA, Universitas Gadjah Mada, Yogyakarta.

Tan, K.H., 1995, Enviromental Soil Science, Marcel Dekker, New York.

Taliwongso, S. 2005. "Pemanfaatan Lignin sebagai Bahan Adsorben untuk Penyisihan Kromium", Dissertasi, Program Sarjana Institut Teknologi bandung, Bandung. 